\title{
COVID-19'la Mücadelenin Aktif Özneleri Olarak Gençler: Salgına Karşı Dünyadan İyi Uygulama Örnekleri
}

Özge Sanem Özateş Gelmez*

Öz

Amaç: COVID-19 salgını, pek çok nüfus grubu gibi gençlerin de fiziksel, zihinsel ve sosyal sağlıkları üzerinde göz ardı edilemeyecek büyüklükte bir tahribat yaratmıştır. Bu süreçte gençler salgın nedeniyle doğrudan ya da dolaylı olarak yaşadıkları sorunların yanında, salgının yayılımının önlenmesi için 102 üzerlerine düşeni yerine getirmedikleri ve sorumsuzca davrandıkları ithamlarıyla da karşı karşıya kalmışlardır. Ancak gençler bir yandan sosyal hizmet ve sağlık çalışanları olarak salgına karşı yürütülen mücadelenin ön saflarında yer almış, öte yandan salgının yayılım hızını yavaşlatacak tedbirlerin alınmasından, salgına bağlı ortaya çıkan sorunların hafifletilmesine kadar oldukça geniş bir yelpazede iyi uygulama örneklerine imza atmışlardır. Bu çalışmada, gençlerin salgından nasıl etkilendikleri ve salgına karşı verilen mücadelede gençlerden nelerin beklendiği konuları tartışıldıktan sonra, gençler tarafından yürütülen iyi uygulama örneklerinin görünür kılınmasına odaklanılmaktadır. Böylece gençler hakkında bu süreçte yayılan olumsuz genellemelerin önüne geçmek ve salgınla mücadelede yürütülebilecek yeni uygulamalara ilham kaynağı yaratabilmek hedeflenmektedir.

Sonuç ve öneriler: Bu çalışmada gençlerin dört kıta, on altı farklı ülkede salgına karşı yürüttüğü iyi uygulama örneklerine mercek tutulmuştur. Dünyanın pek çok yerinde gençler, salgına karşı sağlık ve sosyal hizmet alanında yürüttükleri özverili çalışmaların yanında kendilerinden beklenenin çok ötesinde bir çabayla salgının yayılım hızının yavaşlatılması ve insanların yaşamlarında olumlu değişimler yaratılabilmesi için yiyecek ve ilaç dağıtımı, yanlış bilgilerin düzeltilmesi, önleyici tedbirlerin yaygınlaştırılması gibi önemli uygulamalar gerçekleştirmişlerdir. Bu süreçte salgına karşı verilen mücadeleye hergün daha fazla sayıda gencin katılabilmesi için onların güçlerine ve becerilerine güvenilmesi ve çalışmalarının teşvik edilmesi önemlidir.

Anahtar Kelimeler: Pandemi, Gönüllülük, Gençlik, İyi Uygulama, Mücadele.

* Doç. Dr., Hacettepe Üniversitesi, İktisadi ve İdari Bilimler Fakültesi, Sosyal Hizmet Bölümü, Ankara, sanemozge@gmail. com, ORCID: https://orcid.org/0000-0002-5990-4480 


\begin{abstract}
Purpose: Like other population groups, the physical, mental, and social health of young people also has been adversely affected by the COVID-19 pandemic. Though young people themselves are directly and/or indirectly affected by the pandemic, they have also been accused of not doing their part to prevent the spread of COVID-19 and of acting irresponsibly. However, young people have fought against the pandemic as social and health workers and have presented a wide array of best practice examples, such as taking measures to slow the spread of the pandemic and alleviating pandemic related problems. In this study, first, it has been discussed how young people have been affected by the pandemic and what is expected from them, after which it has been focused on best practice examples. In doing this, it is endeavored to challenge negative stereotypes held about young people and to create a corpus of effective practices that can be implemented to overcome the current pandemic.

Conclusion and recommendations: This study focuses on the best practices by young people during the COVID-19 pandemic in four continents and sixteen different countries. As social and health workers, young people the world over have worked self-sacrificingly against the pandemic. Additionally, they have also carried out important services, such as food and medicine distribution, correction of inaccurate information, dissemination of preventive measures, and creating positive changes in people's lives. During the pandemic, it is important that their strength and skills are trusted and encouraged so that an increasing number of young people can participate in the fight against the pandemic.
\end{abstract}

Keywords: Pandemic, Volunteering, Youth, Best Practice, Struggle.

\title{
Giriş
}

2019 yılının sonlarında ortaya çıkan ve kısa sürede tüm dünyayı etkisi altına alan COVID-19 salgınını Birleşmiş Milletler, bilhassa dezavantajlı kılınmış topluluklar açısından eşitsizlikleri derinleştirmesi ve toplumsal güvensizliği arttırması nedeniyle yalnızca bir sağlık sorunu olarak değil, aynı zamanda bir kültür, ekonomik ve eğitim sorunu olarak değerlendirmekte ve II. Dünya Savaşı'ndan bu yana yaşanan en büyük küresel kriz olarak nitelendirmektedir (UNESCO, 2020b).

Yaşanan bu salgın, dünyanın her yerinde tüm nüfus gruplarından insanların sağlığını olumsuz biçimde etkilemiş ve etkilemeye de devam etmektedir. Gerek sağlıkları üzerinde yarattığı tahribatın daha ağır olması ve iyileşme sürecinin zorlu ve uzun erimli olması gerekse yaşamın sonlanmasına yol açma olasılığının daha yüksek olması bakımından, salgının ileri yaştaki insanlar ile kronik hastalığa sahip her yaştan kişiler için oldukça büyük bir tehdit olduğu kabul edilmektedir. Bununla birlikte Dünya Sağlık Örgütü (DSÖ) tarafından 1948 yılından bu yana değiştirilmeksizin kullanılan tanıma1 göre sağlığın, "hastalık veya sakatlı̆̆ın olmaması değil, tam bir fiziksel, zihinsel ve sosyal iyilik hali"

11946 yılında düzenlenen Uluslararası Sağlık Konferansı'nda kabul edilen, 1948 yılında yürürlüğe konulan Dünya Sağlık Örgütü Anayasası'nda yer alan tanımdır (Official Records of WHO, no. 2, p. 100). 
olduğu göz önünde bulundurulduğunda, gençlerin sağlığının da salgından ciddi biçimde etkilendiğini söylemek mümkündür.

Gençlerin sağlığı üzerinde yarattığı tahribatın yanı sıra salgının yayılım hızının yavaşlatılması için gençlerin üzerlerine düşen sorumlulukları yerine getirmediklerine ve dahası halk sağlığını riske atacak biçimde davrandıklarına ilişkin söylemler özellikle sosyal medya aracılığıyla yaygınlaştırılarak, tekil örnekler üzerinden tüm gençlerin bu süreçteki tavırlarının sorumsuz ve bencilce olduğuna ilişkin genellemelerin yapıldığı görülmektedir. Buna karşın gençler tarafından salgına karşı verilen mücadelelere ise sosyal medyada daha az dikkat çekilmektedir.

Salgının gençler üzerindeki olumsuz etkilerinin ortaya konulması önemli olmakla birlikte, onların bencil ve sorumsuzca hareket ettiklerine ilişin genellemelerin sonlandırılarak, salgına karşı yürütülen mücadelede sessiz sedasız verdikleri çabaların görünür kılınmasına da ihtiyaç duyulmaktadır. Daha fazla sayıda gencin bilgi, beceri ve gücünün salgınla mücadeleye yönlendirilmesini teşvik etmek için dünyanın farklı yerlerinde gençler tarafından yürütülen iyi uygulama örneklerinin duyurulması gerekmektedir.

21. yüzyılın en büyük salgınını yaşadığımız bugünlerde gençler ne bencil ve sorumsuzca davranmakta ne de salgına karşı yürütülen mücadelede pasif bir konumda kalmaktadırlar. Bu çalışma, gençlerin sanılanın aksine, bu mücadelenin aktif özneleri olarak sorumluluk

104 aldıklarını ve girişimlerde bulunduklarını gösteren iyi uygulama örneklerinin görünür kılınması gerektiği üzerine temellendirilmiştir. Bu nedenle çalışmada, salgın nedeniyle yaşadıkları mevcut sorunlar katlanarak artmasına rağmen dünyanın dört bir yanından gençler tarafından salgınla mücadelede yürütülen iyi uygulama örneklerinin ortaya konulması amaçlanmıştır. Bu bağlamda çalışmada aşağıdaki sorulara yanıt aranmıştır:

- COVID-19 salgınından gençler nasıl etkilenmektedir?

- Salgınla mücadele kapsamında gençlerden neler beklenmektedir?

- Salgınla mücadelede gençler tarafından yürütülen iyi uygulama örnekleri nelerdir? Gençler tarafından salgınla mücadelede yürütülen iyi uygulama örneklerinin görünür kılınması, bir yandan gençler hakkında bu süreçte öne çıkan olumsuz genellemelerin önüne geçilmesi, diğer yandan ise salgının sonlandırılmasına katkı sağlayacak benzer uygulamalara ilham vermesi bakımından oldukça önemlidir.

\section{Salgının Gençlerin Fiziksel, Zihinsel ve Sosyal Sağlıkları Üzerindeki Öngörülebilir Etkileri}

Salgın sürecinden önce dahi Birleşmiş Milletler tarafından her beş gençten birinin eğitim, öğretim veya istihdamdan yoksun olduğu ve gençlerin dörtte birinin şiddet veya çatışmayla karşı karşıya kalmış olduğu vurgulanmış (UN, 2020b) ve salgının etkileri karşısında da en savunmasız nüfus grupları arasında yine gençlerin yer aldığının altı çizilmiştir (UNESCO, 
2020b). Zira salgın süreci, gençlerin fiziksel, zihinsel ve sosyal sağlıklarını ciddi biçimde etkileyen yeni koşulları ortaya çıkartmıştır.

COVID-19 salgını, virüse maruz kalan gençlerin fiziksel sağlıklarının bozulmasına ve hatta yaşamlarını kaybetmelerine yol açması bakımından gençler açısından dikkate alınması gereken büyük bir sorundur. Bununla birlikte uygulanan uzun süreli karantina önlemleri nedeniyle fiziksel aktivite düzeylerinde yaşanan düşüş, tüm gençlerin fiziksel sağlıkları üzerinde önemli riskleri beraberinde getirmektedir. Öncen, Aydın ve Molla (2020, s. 746)'nın, spor bilimlerinde öğrenim görmekte olan öğrencilerle yaptıkları araştırmada, olağan koşullarda fiziksel aktivite düzeyleri yüksek olan gençlerin yaşam alanlarında geçirdikleri zamanın artmış olmasıyla birlikte toplam fiziksel aktivite düzeylerinde anlamlı bir düşüş yaşandığı sonucuna ulaşmışlardır.

Salgının durdurulabilmesi için birçok ülkede uygulanmak zorunda kalınan okulların kapatılması ve sosyal etkinliklerin iptal edilmesi gibi düzenlemeler ve alınan uzun süreli karantina önlemleri, gençlerin kişisel gelişimi ve kimlik oluşumunda oldukça önemli bir payı olan akran ilişkilerini ve sosyal yaşama katılımlarını da büyük ölçüde kısıtlamıştır. Ekonomik İşbirliği ve Kalkınma Örgütü'nün (OECD) verileri, alınan bu tür önlemlerin gençler üzerinde strese, endişeye ve yalnızlığa neden olan önemli psikolojik etkilerini doğrulamaktadır (OECD, 2020g, s. 11). Üniversite öğrencileriyle yaptığı araştırmada Tekin (2020, s. 1141) salgın sürecinde gençlerin sosyalleşme kaygısının arttığını ve sosyalleşme ile ilgili kaygıların hem içsel motivasyonlarını hem de dışsal motivasyonlarını olumsuz etkilediği sonucuna ulaşmıştır. Ayrıca diğer yaş gruplarıyla karşılaştırıldığında gençlerin internet ve sosyal medya aracılığıyla COVID-19 salgınının sonuçlarına ilişkin daha fazla duyuma maruz kaldıklarının ve bu durumun da gençleri psikolojik olarak daha çok etkilediğinin altı çizilmektedir (Akat ve Karataş, 2020, s. 2). COVID-19 salgınında bireylerin algıladığı stres ve kaygı düzeylerini inceledikleri araştırmalarında Göksu ve Kumcağız (2020, s. 475) ise 20-29 yaş grubundaki gençlerin, salgın sürecini daha stresli algıladıklarını ve salgının sürekli kaygı düzeyleri üzerindeki olumsuz etkilerini de daha çok hissettiklerini ortaya çıkartmışlardır. Ek olarak salgın nedeniyle alınan önlemlerin, zihinsel sağlık sorunları olan pek çok gencin sağlık durumlarının daha da kötüye gitmesine ve ruh sağlığı sorunları yaşayan gençlerin sayısının da artmasına neden olduğu bilinmektedir (Lee, 2020).

Salgın sürecinde, dezavantajlı kılınmış gençlerin de büyük bir risk altında olduğu kabul edilmektedir. Bilhassa yoksul, engelli, göçmen, mülteci ve HIV/AIDS'le yaşayan gençlerin sağlık hizmetlerine ve sosyal korumaya erişim olanaklarının daha da kısıtlandığına ve sabit konutlarda ikamet edemeyen gençlerin de ev tabanlı fiziki mesafe önlemlerine güvenli bir şekilde uyum gösterme imkanlarının olmadığına dikkat çekilmektedir (UNDESA, 2020). 
Önceki salgınlarda alınan karantina önlemleri sırasında, aile içi şiddet vakalarının arttığı ve özellikle kadınların, ergenlerin ve çocukların aile içinde yaşanan şiddete karşı savunmasız kalabildikleri görülmüştür (OECD, 2020f, s. 24). Karantina önlemleri sırasında aile içinde şiddete maruz kalanların başka bir yere sığınma olanaklarının kısıtlandığına ve bu nedenle uygulanan baskı, kontrol ve şiddetin yoğunluğunun artması riskinin de ortaya çıktığına dikkat çekilmektedir (OECD, 2020f, s. 13). Aile içi şiddet vakalarının yanı sıra internet kullanımının yoğunlaşmasıyla birlikte gençlerin dijital şiddete karşı da daha savunmasız kalabileceği vurgulanmaktadır (Ragavan, Culyba, Muhammad ve Miller, 2020, s. 18). Bu süreçte gençlerin dijital şiddetle karşı karşıya kaldıklarında şiddetten kurtulabilmeleri için öğretmenlere ve sosyal hizmet uzmanları gibi profesyonellere düzenli erişim olanaklarından yoksun kalma riski de artmaktadır (Green, 2020, s. 1).

Birleşmiş Milletler Nüfus Fonu (UNFPA) İcra Direktörü Natalia Kanem tarafından Uluslararası Gençlik Günü dolayısıyla yapılan açıklamada, yaşanan salgın sürecinde gençlerin tercih olanaklarının sınırlanması sorununun yanı sıra çalışma, eğitim ve sağlık gibi temel haklarının korunmasını sağlayacak düzenleme ve hizmetlere erişim olanaklarının yitirilmesi sorunuyla da karşı karşıya kaldıkları vurgulanmıştır (Kanem, 2020). Zira salgın sürecinde gençlerin yaşadığı temel hak ihlallerinin başında eğitim gelmektedir. Salgın nedeniyle dünyanın hemen her yerinde tüm öğrenim düzeylerinde çevrimiçi bir öğrenme modeline geçiş yapmak zorunda kalınmıştır. Birleşmiş Milletler Eğitim, Bilim ve Kültür Örgütü'nün (UNESCO) kayıtlarına göre, salgının dünya genelinde yayılım göstermesinin ardından 193 ülke genelinde yüz yüze eğitim uygulamaları sonlandırılmış ve okullar kapatılmıştır. Bu düzenlemeler kayıtlı öğrencilerin yaklaşık \%92'sinin (1.5 milyarın üstünde gencin) okula gidememesine neden olmuştur (UNESCO, 2020a). Eğitim alanında alınan bu türden önlemlerin, pek çok gencin öğrenim sürecini aksatabileceği ve mezuniyet oranlarını olumsuz etkileyebileceği öngörülmektedir. Gençlerin eğitim ve öğretimde yaşanan kesintilerden kaynaklanan performans düşüşleri ve motivasyon kayıpları yaşayabileceklerine, destekleyici yetişkinlerle bağlantı kurmaktan ve olumlu akran etkileşimlerinden yoksun kalabileceklerine dikkat çekilmektedir (OECD, 2020a, s. 21).

Okulların kapatılmasının ya da yüz yüze eğitime ara verilmesinin, özellikle yoksul öğrenciler için büyük bir sorun yaratacağı da düşünülmektedir. OECD’nin hazırladığı bir raporda, bilhassa sosyo-ekonomik açıdan dezavantajlı olan 15 yaşındaki öğrencilerin \%9'unun evde ders çalışmak için sessiz bir ortamının olmadığının, yoksul ülkelerde yaşayan öğrencilerin \%34'ünün bilgisayara erişimi olmadığının, ayrıca öğrencilerin yarısının çevrimiçi eğitimin gerektirdiği internete erişiminin bulunmadığının ve internet erişimi için coğrafyanın da önemli bir etken olduğunun altı çizilmektedir (OECD, 2020c, s. 1-3). Yaptıkları araştırmada Karahan, Bozan ve Akçay (2020, s. 212), üniversite öğrencisi 
gençlerin teknolojik yoksunluk içinde oldukları ve yaşadıkları bölgeler nedeniyle internet erişimlerinin olmamasının salgın sürecindeki çevrimiçi öğrenme süreçlerini olumsuz etkilediğini ortaya koymuşlardır. Öğretmenlerle gerçekleştirdikleri araştırmada Demir ve Kale (2020, s. 3447); internetlerinin olmaması, öğrencilerin donanımsal araçlarının yetersizliği ve velilerin teknolojik bilgi eksikliği gibi nedenlerle öğrencilerin çevrimiçi eğitime erişim konusunda sorun yaşadığını ortaya çıkartmışlardır.

Beslenme ve sağlık ihtiyaçlarının karşılanmasında okulların sunduğu desteklere gereksinimi bulunan öğrencilerin de yaşam standartlarının çok daha düşeceğine ilişkin olumsuz bir tablo çizilmektedir (UNDESA, 2020). Mesleki eğitim ve öğretimin ise diğer eğitim ve öğretim biçimlerine klyasla daha fazla uygulama gerektirmesi nedeniyle, uzaktan öğrenmeye daha az uyarlanabilir olduğu ve bu nedenle salgın sürecinde eğitim alanında yapılan düzenlemelerin, bu türden eğitim alan gençlerin öğrenme süreçlerini olumsuz etkilediği vurgulanmaktadır (OECD, 2020a, s. 21).

OECD tarafından hazırlanan "How's Life? 2020" raporunda, 15-24 yaş arası her on gençten birinin eğitimin yanı sıra istihdama da katılamadığı ve OECD ülkeleri için bu durumun uzun süredir devam eden bir sorun olduğu vurgulanmıştır (OECD, 2020b, s. 90). Olağan koşullarda dahi 15 ila 24 yaşları arasındaki gençlerin işsizlik sorunuyla karşı karşıya kalma olasılığının yetişkinlere kıyasla üç kat daha fazla olduğu bilinmektedir. 19992019 yılları arasında küresel genç nüfus, 1 milyardan 1.3 milyara yükselmesine rağmen, işgücüne dahil olan toplam genç sayısı (çalışan ya da işsiz) 568 milyondan 497 milyona düşmüştür. Küresel olarak gençlerin beşte biri şu anda ne eğitimde ne istihdamda yer almakta ve bu gençlerin büyük çoğunluğunu genç kadınlar oluşturmaktadır (ILO, 2020, s. 13). Ayrıca diğer yaş gruplarına göre gençlerin güvencesiz çalışma olasılığı daha yüksek olup dünya genelinde gençlerin yaklaşık \%77'si kayıt dışı istihdam edilmekte ve bu oran özellikle düşük ve orta gelirli ülkelerdeki genç kadınlar için daha da yüksek seyretmektedir. Dahası istihdamda olan gençlerin \%30'nun dahi, aşırı ve orta derecede yoksulluk içinde yaşadığı tahmin edilmektedir (ILO, 2020, s. 23- 24). İşsizlik oranları şubat ayında \%5.2 iken Mart 2020'de salgının etkisiyle \%5.6'ya yükselmiştir. OECD genelindeki işsizlik oranının 2020’nin dördüncü çeyreğinde ise \%9.4'e kadar yükselebileceği düşünülmektedir (OECD, 2020d; OECD, 2020e). Salgın sonrasında işsizlikte yaşanan söz konusu artışın, 2009 küresel ekonomik krizinden sonra yaşanan işsizlik oranlarındaki artışı dahi aşacağı ve zaten dezavantajlı olan gençlerin, yaşanacak krizden orantısız bir şekilde etkileneceği tahmin edilmektedir (UNDESA, 2020).

Sağlık sigortasının istihdamla bağlantılı olduğu ülkelerde istihdam alanında dezavantajlı kılınmış olan gençlerin sağlık hakkının da korunmadı̆̆ı, istihdama dahil olan gençlerin bir bölümünün ise kayıt dışı sektörlerde çalıştıkları veya çalışan yoksullar arasında oldukları için sağlık hizmetlerine erişimlerinin büyük ölçüde olmadığı raporlanmaktadır. 
Ayrıca salgın sürecinde yaşanan ekonomik durgunluğun, belirli genç gruplara karşı damgalamaları ve ayrımcılığı körükleyebileceği gibi ayrımcılığın bu gençlerin sağlık hizmetlerine erişimini daha da engelleyebileceği düşünülmektedir (UNDESA, 2020; UNESCO, 2020b).

Dolayısıyla gençler, tüm diğer nüfus grupları gibi salgının yarattığı olumsuz koşullardan fazlasıyla etkilenmiştir ve etkilenmeye de devam etmektedirler. Bu sürecin sosyal ve ekonomik koşullar üzerinde yarattığı olumsuzluklardan en fazla etkilenen nüfus grupları arasında yer alan gençler hem salgının zorunlu kıldığı yeni yaşam koşullarına ayak uydurmaya çalışmakta hem de herkes gibi sağlıklarını koruyabilme kaygısını yaşamaktadırlar. Buna rağmen gençler, yalnızca bireysel düzeyde iyilik hallerine odaklanmamış, salgınla mücadelenin ön saflarında yer almaya başlamışlardır. Sorunun önemine binaen, daha fazla sayıda gencin salgına karşı yürütülen mücadelenin aktif özneleri olarak rol oynayabilmeleri için atabilecekleri adımlara da küresel kamuoyunda gitgide daha çok dikkat çekilmektedir.

\section{Salgınla Mücadelede Gençlerden Beklentiler}

Salgınla mücadelede atılabilecek adımlara ilişkin bildirisinde Birleşmiş Milletler, olağan koşullarda gençler tarafından oldukça etkili kullanılan sosyal medyanın, bir panik alanı olarak değil, ussal ve sakin bir biçimde bir dayanışma alanı olarak sağlıklı iletişim ve toplum refahı için kullanılmasının önemine dikkat çekmiştir. Belirsizlik dönemlerinde doğru olmayan haberlerin oldukça hızlı biçimde yayıldığının ve konuyla ilgili herhangi bir haberin paylaşılmadan önce doğrulanması gerektiğinin altının çizildiği bildiride, bunun, içinde bulunduğumuz süreçte ihtiyaç duyulan ussal ortamın yaratılabilmesinde özellikle gençler için kolaylıkla ve istisnasız bir biçimde atılabilecek bir adım olduğu da vurgulanmıştır (UN, 2020a). Otuz yaşın altındaki genç liderlerden oluşan bir ağ olan ve elliyi aşkın ülkede faaliyet yürüten Global Shapers Community de doğru bilgiye ulaşım kaynaklarını en etkili biçimde kullanabilen nüfus grubu olarak gençlerin, toplumda salgınla ilgili doğru bilinen yanlışları ortadan kaldırabilmek için ulaştıkları güvenilir bilgilerden başkalarının da haberdar olmasını sağlayabileceklerini belirtmiştir (WEF, 2020). Radyo, kısa mesaj, video konferans gibi platformların yenilikçi kullanımıyla iletişim kurmanın yeni yollarını keşfetme becerisine sahip gençlerin, özellikle dijital teknolojilere erişimi olmayan toplulukların bilgiye ulaşımını sağlayarak, salgın sürecinde önemli bir sinırlılık olarak ortaya çıkan dijital uçurumun aşılabilmesi için de oldukça kritik bir rol üstlenebileceklerinin altı çizilmektedir (UNFPA ve IFRC, 2020, s. 10).

Bu süreçte ihtiyaç duyulan ussal iletişimin yanı sıra gençlerin, bilhassa yaşlılara ve kronik hastalıkları olanlara yiyecek ve ilaç temininde sağlayacakları destekle kendi toplumları için gönüllü olabileceklerine dikkat çekilmektedir. Dahası dünyanın dört bir yanındaki sağlık çalışanlarının, kliniklerde ve hastanelerde hayat kurtarmak üzere oldukça riskli 
koşullarda çalışırken onların çocuklarına veya bakıma ihtiyaç duyan ebeveynlerine bakmak için gençlerin yardımına ihtiyaç duyabileceklerinin de altı çizilmektedir (UN, 2020a).

Sosyal politika düzeyinde ise gençlerin, ücretsiz testlerin erişilebilir olması, güvenilir bilgiye ulaşım, ücretli hastalık izninin tanınması, salgınla mücadelede bilimsel çalışmalara yatırım yapılması ve evrensel sağlık sigortası için savunuculuk yapmaları gerektiği belirtilmektedir (UN, 2020a). Gençlerin salgın sürecinde ve sonrasında ergen sağlığı programlarını ve politikalarını tasarlama ve uygulama şeklini dönüştürme gücüne sahip oldukları, salgından etkilenen politikaları, sistemleri, iş akışlarını ve toplulukları yeniden yapılandırmak için stratejik planlara katılmayı talep etmeleri gerektiği de vurgulanmaktadır (Efuribe, Barre-Hemingway, Vaghefi ve Ballonoff Suleiman, 2020, s. 17). Gençlerin; sosyal uyumu teşvik etme, nefret söylemi, yabancı düşmanlığı, insan hakları ihlalleri ve şiddetle mücadele gibi konularda güçlü ve kapsayıcı girişimler oluşturarak krizin uzun vadedeki etkisini ve sonuçlarını hafifletmeye yardımcı olabilecekleri de ifade edilmektedir (UNFPA ve IFRC, 2020, s. 10).

Ancak önerilen tüm bu girişimlerden önce kişisel bakım ve hijyene dikkat edilmesi, fiziki mesafe önlemlerine uyulması, hasta hissedildiğinde evde kalınması da dahil olmak üzere gençlerin kapsamlı önlemler almaları ve bu konuda da toplumu teşvik etmeleri gerektiğinin sıklıkla altı çizilmektedir (WEF, 2020).

Dünyanın hemen her yerinde gençler, küresel kamuoyu tarafından vurgulanan tüm bu beklentilerin ötesine geçerek salgınla mücadele kapsamında iyi uygulama örneklerine imza atmaktadırlar. Çalışmanın sonraki bölümünde farklı kıtalardaki gençler tarafından salgına karşı yürütülen bazı uygulamalar ele alınmaktadır.

\section{Salgınla Mücadelede Gençlerden İyi Uygulama Örnekleri}

Gençler, bir yandan salgın sonucu bir zorunluluk olarak ortaya çıkan yeni yaşam koşullarına hızla uyum sağlarken, diğer yandan salgının durdurulabilmesi için sürecin başından bu yana ve giderek artan biçimde salgınla mücadelede önemli bir rol oynamaktadırlar. Bu süreçte gençlerin bir bölümü, mesleki uzmanlıkları gereği sosyal hizmet ve sağlık çalışanları olarak, gerek sağlık hizmetlerinin aksamadan ve hızla sunulabilmesi için gerekse yardıma ve desteğe gereksinimi olan insanların ihtiyaçlarının karşılanması için oldukça yoğun bir iş temposu altında dünyanın dört bir yanında çalıştılar ve çalışmaya da devam etmekteler. Koruyucu ekipman eksikliğine rağmen, genç sağlık çalışanları ve öğrenciler salgınla mücadelenin ön saflarında hayatlarını riske atmaktadırlar. Genç kadın ve erkek araştırmacılar ve uzmanlar, hayat kurtarıcı önlemlerin alınmasına ve tıbbi cihazların geliştirilmesine katkıda bulunarak salgınla mücadeleye destek olmaktadırlar (UNFPA ve IFRC, 2020, s. 10). 
Daha göz önünde olan bu emeğin yanı sıra gençlerin bir diğer bölümü ise daha az görünür ancak oldukça hayati öneme sahip bir çabayla salgınla mücadelenin ön saflarında yer almaktadırlar. Söz konusu gençler özellikle salgının yayılım hızının yavaşlatılabilmesi için doğru bilgiye ulaşım olanakları kısıtlı olan insanların bilgilendirilmesinde, toplumun farklı kesimlerinin farklılaşan ihtiyaçlarının görünür kılınmasında, sağlık ve sosyal hizmetlere erişim güçlükleri yaşayan insanların yaşadığı sorunlara dikkat çekilmesinde önemli bir rol üstlenerek, bu konuda politika yapıcılar tarafından alınacak önlemlere yön verilmesinde önemli katkılar sağlamaktadırlar.

Gençler; topluluklarındaki bilgi kirliliğine, bu süreçte üretilen mitlere ve ayrımcılıklara karşı geliştirdikleri savunuculuk faaliyetleriyle, topladıkları verilerle korku ve güvensizliklere karşı mücadele etmekte, diğer insanları harekete geçirmek için gönüllü olmakta, el yıkama kampanyaları gibi kampanyalarla olumlu davranış değişimi için çaba göstermekte, karantinaya alınmış evlerde ihtiyacı olan kişilerin yiyecek ve gıda dışı öğelere ulaşmasında destek sağlamaktadırlar (UNFPA ve IFRC, 2020, s. 10). OECD (2020g, s. 26) tarafından yapılan bir araştırmaya göre dünyanın dört bir yanında gençlik örgütleri, okulların ve destek hizmetlerinin kapatılmasının yarattığı olumsuz etkileri hafifletmek, yalnızlığı ve endişeyi gidermek ve sosyal uyumu teşvik etmek için oldukça önemli uygulamalar geliştirerek doğru bilgiye erişimi kolaylaştırmış, karantinada yaşayan ergenleri, genç yetişkinleri ve yaşlıları desteklemiş, etiketleme ve ayrımcılıkla mücadele etmişlerdir. Söz konusu araştırmaya göre gençlerin liderlik ettiği her dört kuruluştan üçü, kendilerini ve başkalarını korumaya yönelik önlemler hakkında bilgilendirici çevrimiçi kampanyalar oluşturmuşlardır. Kuruluşların yarısından fazlası ise zihinsel ve fiziksel sağlı̆ın nasıl korunacağı, etiketleme ve ayrımcılıkla nasıl başa çıkılacağı konusunda gençlere tavsiyelerde bulunmak için dijital ve çevrimiçi araçlar sağlamışlardır (OECD, 2020g, s. 26).

Salgın sürecinin en başından bu yana gençler tarafından salgına karşı farklı biçimlerde yürütülen mücadeleler, kimi zaman bireysel girişimler olarak sınırlı bir çevrede, kimi zaman da gençlik örgütleri tarafından daha geniş kitlelere ulaşılmasıyla dünyanın hemen her yerinde yürütülmektedir. Bu çalışmada öncelikle salgının başladığı kıta olan Asya kıtası başta olmak üzere toplam dört kıtada salgın karşısında gençler tarafından başlatılan ve sürdürülen iyi uygulama örneklerine mercek tutulmuştur.

\section{Yağmurluklu Genç Kadından Koronavirüs Haritasına Asya Kıtasından İyi Uygulama Örnekleri}

Salgının başladığı çin’in Wuhan kentinde, salgınla mücadelenin ön saflarında yer alan sağlık çalışanlarının uzun çalışma saatleri süresince yemek yeme olanakları restoranların da kapalı olması nedeniyle oldukça kısıtlanmıştır. Sağlık çalışanlarının ev yemeğine ulaşım zorluğunu gören 24 yaşındaki genç kadın Xian Lu, kentin sağlık 
personeli için yemek pişirmeye ve dağıtmaya başlamıştır. Zorlu hava koşullarına rağmen üzerine giydiği yağmurluğuyla, pişirdiği yemekleri sağlık personellerine ulaştırmak için çalışan Lu, kıyafeti nedeniyle kısa sürede "yağmurluklu genç kadın” olarak tanınmıştır. 40 günde 20.000'den fazla yemek pişirmiş ve dağıtmış olan Lu'nun girişimi, dünyanın dört bir yanından gence ilham kaynağı olmaya devam etmektedir (Wickramanayake, 2020). Grigor Yeritsyan, ülkesi Ermenistan'da salgın nedeniyle evlerinden ayrılamayan yaşlılara yiyecek sağlamak için ‘Armenian Progressive Youth' isimli gençlik örgütüyle birlikte çalışmaktadır. Ülkedeki mevcut sosyo-ekonomik eşitsizlikler devam ederken ülkenin en dezavantajlı kılınmış grupları olan yaşlılar, engelliler, kronik hastalıkları olanlar, bekar anneler, gündelik işlerde çalışanlar ve işsiz gençler salgından oldukça olumsuz etkilenmiştir. Bu nüfus gruplarından insanların salgın öncesinde de yetersiz beslenme ve sağlık hizmetlerine erişim sorunu olması, salgınla durumlarının daha da kötüleşmesine ve neredeyse yoksulluktan ve açlıktan yaşamlarını yitirme riskiyle karşı karşıya kalmalarına sebep olmuştur. Söz konusu gençlik örgütü, salgınla mücadele için başlattıkları bağış toplama kampanyasıyla salgının, söz konusu nüfus grupları üzerindeki etkisine karşı koymak için harekete geçmiştir. Kampanyanın başlatılmasını takip eden ilk dört gün içinde yaşlılar, bekar anneler ve yüksek risk altındaki işsizler için aylık olarak tüketebilecekleri yiyecekleri ve diğer malzemeleri satın almaya yetecek miktarda bağış toplanmış, beslenme uzmanları tarafından hazırlanan hijyen malzemeleri ve yiyeceklerden oluşan kutular bu kişilere ulaştırılmıştır. Ayda 4.000 kişiye yiyecek sağlama hedefiyle çalışan gençlik örgütü, yerel yönetim ve hükümetlerle işbirliği yaparak, hedef gruplar için aylık sarf malzemeleri ve sıhhi tedarik kutuları sağlamayı sürekli hale getirmeyi amaçlamaktadır. Ayrıca gönüllü gençler, el ilanları dağıtarak salgından korunma yolları, fiziki mesafenin önemi ve kendilerini hasta hissetmeleri durumunda insanların izlemesi gereken temel adımlar hakkında bilgilendirme yapmaktadır (One Young World, 2020; Yeu, 2020).

Bangladeş'te Muhammed Ferdaus, kurucusu olduğu Community Development for Peace örgütü aracılığıyla gecekondu bölgelerinde salgın sürecinde daha da zorlaşan sağlık ve güvenlik koşullarının sürdürülebilmesi için çalışmaktadır. Bangladeş’in, Dakka kentinde yer alan ve ülkenin en büyük gecekondu mahallelerinden biri olan Korail'de başlattıkları uygulamayla hem salgın konusunda bir farkındalık programı geliştiren hem de iletilen gıda ve temizlik ürünlerini dağıtım programı düzenleyen Ferdaus ve arkadaşları, sokak satıcıları gibi gündelik işlerde çalışanlar için kuru gıda ve temizlik kitleri dağıtmakta ve hijyen konusunda eğitimler vermektedirler. Halihazırda ülkenin en yoksul nüfusunun yaşadığı söz konusu mahallede salgının hızla yayılması nedeniyle bölge karantina altına alınmıştır. Bu nedenle, oldukça kötü yaşam koşullarında yaşayan ve son derece düşük gelirli işlerde çalışan insanların karşı karşıya kaldığı beslenme ve sağlık sorunları, 
insanlara acil kullanımları için düzenli gıda yardımını ve hijyenik kit dağıtımını daha da önemli hale getirmiştir (Women Deliver, 2020; Bracu, 2020).

Kore Cumhuriyeti'nden 27 yaşındaki Lee Dong-hun, Ocak 2020'de 'Coronamap' isimli bir dijital uygulama geliştirerek salgın sürecinde ihtiyaç duyulan doğru bilgiye ulaşımı sağlama yönünde oldukça önemli bir girişim başlatmıştır. Ülkedeki mevcut vakaların yerini belirlemeyi hedefleyen, gerçek zamanlı bir takipçi olarak geliştirilen, İngilizce ve Korece dillerinde kullanılabilen koronavirüs haritası sayesinde COVID-19 testi pozitif çıkanlarla ve iyileşmiş hastalarla ilgili günlük olarak güncellenen istatistiklere herkesin kolayca ulaşabilmesi sağlanmıştır. Dong-hun, salgının ilk aşamasında sosyal medyada doğru olmayan çok sayıda haberin yayılması ve insanlar arasında büyük bir korkunun yaşanmış olması nedeniyle, doğru bilgiye ulaşımı sağlamak ve korkuyu hafifletmek için böyle bir uygulamayı geliştirdiğini belirtmiştir. Dong-hun, kümülatif doğrulanmış hasta sayısının artmasına rağmen, insanların salgın konusundaki bilincinin artması ve gönüllü üniversite öğrencilerinin de desteğiyle başlarda zor olan uygulama yönetiminin artık daha kolay olduğunu ifade etmiştir. Dong-hun, uygulamanın başarısına rağmen, hayalinin, yeni doğrulanan hasta sayısının bir an önce sıfıra düşerek, Coronamap uygulamasını sonlandırmak olduğunu vurgulamıştır (Kyoung Mi ve Jihae, 2020).

\section{Çalışma Odalarından Evde Yardıma Avrupa Kıtasından İyi Uygulama Örnekleri}

Abdelhamid Idrissi isimli genç, Hollanda'nın başkenti Amsterdam'da 2011 yllında başlattığı 'çalışma odaları' projesiyle şehrin yoksul mahallelerinden çocuklar için şehrin merkezinde ev ödevlerini yapabilecekleri, dersleri için destek alabilecekleri sessiz ve güvenli bir ortam sağlamayı hedeflemiş ve yedi yüzü aşkın çocuğa ulaşmıştır. Salgın nedeniyle çalışma odaları kapanmak zorunda kaldığında öncelikle çocuklara sağladıkları ders desteklerine çevrimiçi olarak devam etmeyi düşündüklerini ifade eden Idrissi, bu çocukların çevrimiçi eğitim alabilmeleri için gerekli olan bilgisayar ve internet bağlantısı ihtiyacının, salgın nedeniyle gelirleri büyük ölçüde azalmış olan aileleri tarafından karşılanmasının da mümkün olmadığını gördüklerini belirtmiştir. Idrissi, çocukların bu süreçte ne türden ihtiyaçları olduğunu ortaya çıkartabilmek için öncelikle telefonla iletişim sağladıklarını ve çocukların bilgisayar ve internet erişiminin çok ötesinde başka sorunlar yaşadıklarını tespit ettiklerini vurgulamıştır. Idrissi ve arkadaşları öncelikle, geçmiş yıllarda gerçekleştirdikleri iyi uygulamalar sayesinde edindikleri sosyal sermayelerini kullanarak bir yiyecek firmasından gıda paketleri temin etmiş ve ebeveynleri salgın sürecinde işsiz kalan çocukların evlerine düzenli olarak bu paketlerin ulaştırılmasını sağlamışlardır. Ayrıca bir internet sağlayıcısı firmayı, söz konusu çocukların çevrimiçi eğitimlere ulaşabilmelerini sağlamak için düzenleme yapmaya ikna etmişlerdir. Son olarak bilgisayarı olmayan çocuklar için yerel yönetimden dizüstü bilgisayarlar temin etmişlerdir. Idrissi, hala çözülmesi gereken pek çok yeni sorunla 
karşılaşmalarına rağmen kazandıkları deneyimleri, daha iyi uygulamalar geliştirmek üzere salgın sonrasında da kullanabileceklerini ifade etmektedir (Buijzen, 2020).

Avrupa'nın en yüksek göç oranlarından birine sahip olan Moldova'da, ülke nüfusunun yaklaşık beşte birini oluşturan 60 yaş ve üstü nüfus, çoğunlukla yalnız ve yoksulluk koşullarında yaşamaktadır. Salgın nedeniyle alınan karantina önlemleri, yaşlıların evlerinden ayrılmalarının önünde engel yarattığı gibi komşularının ve farklı ülkelere göç eden çocuklarının ziyarete gelmelerinin de mümkün olmadığı yeni koşulları ortaya çıkartmıştır. UNFPA tarafından finanse edilen, gençler ve yaşlılar arasında kuşaklar arası bağları kurmayı amaçlayan bir proje kapsamındaki genç gönüllüler, psikologlardan ve epidemiyologlardan aldıkları eğitimlerin ardından yalnız yaşayan yaşlılara ulaşarak onlarla düzenli telefon görüşmeleri yapmakta ve fiziksel mesafeyi koruyarak yaşlı bireylerin evlerine ziyaretler gerçekleştirmektedirler. Uygulama kapsamında gençler tarafından iki yüze yakın yaşlıya ulaşılarak karantinanın yarattığı yıkımların önüne geçmek hedeflenmektedir. Proje gönüllülerinden lise öğrencisi Nelea Ungureanu, yaşlllarla kurduğu ilişkilerden çok yararlandığını ve bu uygulama sayesinde yaşlı insanların hayat hikayelerini öğrenme şansı elde ettiğini ifade etmiştir. Başka bir genç gönüllü olan Maria Negru, uygulamanın her iki nesle de fayda sağladığını, çoğu zaman yaşlılarla kurduğu ilişkilerin kendisini güçlendirdiğini belirtmiştir (UNFPA, 2020).

Bosna-Hersek'in başkenti Saraybosna'da yirmi gönüllü gençle başlatılan uygulama sayesinde salgın nedeniyle uygulanan karantina önlemleri sirasında evlerinden ayrılmaları mümkün olamayan ya da evlerinde kalmaları gereken kişilerin evcil hayvanlarının ihtiyaçları ücretsiz olarak karşılanmaktadır. 'Patilerinizle yürüyoruz' isimli uygulama kapsamında gönüllü gençler, paylaşılan telefon numaralarından kendilerine ulaşan kişilerin köpeklerini, kimi zaman günde iki kez dışarı çıkartarak kimi zaman mama ve diğer ihtiyaçlarını temin ederek salgın sürecinde insanların evcil hayvanları için endişelenmelerinin önüne geçmeyi hedeflemektedir (Sarajevskasehara, 2020).

İngiltere'de Sal Mohammed isimli genç tarafından geliştirilen 'Connected Homeless' isimli dijital platform aracılığıyla salgın sürecinde 'evde yardım' isimli bir uygulama başlatılmıştır. $\mathrm{Bu}$ uygulama kapsamında karantina koşulları altında evlerinden ayrılamayan kişilerin yardım taleplerinin karşılanması hedeflenmiştir. Evde yardım uygulaması, yardıma gereksinim duyan kişilerin destek taleplerini iletebilecekleri ve bu talepleri karşılayabilecek gönüllülerle bağlantı kurabilecekleri bir platform sağlamıştır. Bu uygulama kapsamında gönüllü gençler, gereksinim duyan kişilerin bir yandan kendi toplumlarıyla bağlantıda kalmaları, diğer yandan ise temel hizmetlere erişimleri için aracılık etmektedirler (One Young World, 2020). 


\section{İnfodemiyle ${ }^{2}$ Mücadeleden 'Bir Kişi Bir Dezenfektan'a Afrika Kıtasından İyi Uygulama Örnekleri}

Ruanda'da 5.000'den fazla gönüllü genç, salgınla mücadele için sağlık otoriteleri tarafından yayınlanan kılavuz ve protokollere göre COVID-19 konusunda önleyici ve koruyucu önlemler hakkında herkesin anlayabileceği bir dilde bilgileri paylaşmaktadır. Gönüllü gençler, salgının yayılma hızını yavaşlatmak ve sağlık kuralları konusunda insanları bilgilendirmek için başkent Kigali sokaklarında, pazar girişlerinde, parklarda ve otobüs duraklarında, 08:00-14:00 ve 14:00-19:00 saatlerinde olmak üzere iki vardiya biçiminde çalışmaktadırlar. Bu gönüllüler arasında yer alan Michel Kanamugire isimli genç, üzerine giydiği sarı yelekle Kigali'de bir pazar yerinde alışveriş yapanlara ve satıcılara maske takmanın, elleri düzenli olarak yıkamanın, gözlere, ağza ve burna dokunmaktan kaçınmanın ve fiziksel mesafeyi korumanın önemini anlatmaktadır. Kanamugire, insanların \%80'inin verilen tavsiyeleri ciddiye aldığını ifade etmektedir (Tasamba, 2020). Zimbabve'de yirmi gönüllü genç, mart ayından bu yana sosyal medya ve radyo programlarını kullanarak salgına dair dolaşıma sokulan "alkol içmek virüsü öldürür, kullanılan maskeler paylaşılabilir, Afrikalılar bu virüsten etkilenmezler, salgın diye bir şey yok" gibi söylentilere karşı mücadele vermektedir. Gönüllü gençler, bir sivil toplum örgütü olan 'Voluntary Service Overseas' çatısı altında yürüttükleri uygulamayla salgınla ilgili yapılan çevrimiçi yorumları Zimbabve'nin on altı resmi dilinde tarayarak, 'infodemiye' karşı mücadele vermektedir. Bridget Mutsinze isimli gönüllü genç, salgın sürecinde cehaletin mutluluk değil, ölüm getirdiğini ve bu nedenle salgının yayılmasını önlemek için mümkün olduğunca çok Zimbabveli'ye ulaşmaya çalıştıklarını ifade etmektedir. Gönüllüler, DSÖ tarafından sağlanan bilgileri kullanarak şimdiye kadar 100.000 kişiye ulaşmış ve yanlış bilgilerin düzeltilmesini sağlamışlardır. Mutsinze, yanlış bilgileri düzeltmedikleri takdirde insanların istedikleri gibi yaşamaya devam edeceklerini ve salgından etkilenen kişi sayısının artmaya devam edeceğini vurgulamaktadır (Harrisberg ve Ndhlovu, 2020).

Kamerun'da bir gençlik örgütü olan 'Local Youth Corner' tarafından "bir kişi bir dezenfektan” kampanyasıyla 10.000'den fazla el dezenfektanı üretilerek dağıtılmıştır. Örgütün koordinatörü 26 yaşındaki Achalake Christian, salgının özellikle yoksul yurttaşlar arasında yayıldığını, bunu önlemek için bir girişimde bulunmaları gerektiğini düşündüklerini ifade etmiştir. Christian ve arkadaşları, önce el dezenfektanları satın alıp dağıtmayı düşünmüşler ancak salgın sürecinde iki katı fiyatla satılan dezenfektanlar için ayırabilecekleri ölçekte bir bütçeleri olmadığını görmüşlerdir. Bunun üzerine DSö standartları doğrultusunda tıp doktorları, eczacılar ve laborantların desteğiyle ev yapımı el

2 Söylenti salgını olarak çevrilebilecek olan infodemi kavramını, Dünya Sağlık Örgütü Genel Direktörü Tedros Adhanom Ghebreyesus, Şubat 2020'de Münih'de gerçekleştirilen Güvenlik Konferansı'nda, salgınla ilgili yanlış bilgilerin yaygınlaştırılmasına dikkat çekmek üzere "salgınla olduğu kadar infodemiyle de mücadele ediyoruz" sözleriyle dile getirmiştir (WHO, 2020). 
dezenfektanları üretmeye başlamışlardır. Gençler bir yandan ürettikleri dezenfektanları, insanlara ücretsiz dağıtırken diğer yandan da salgının yayılmasıyla ilgili riskler hakkında insanların farkındalıklarını arttırmaya çalışmaktadırlar (Obonyo, 2020).

2019 yılında bir yetenek yarışması olan America's got Talent'in finaline ulaşmasıyla ismini duyuran Güney Afrikalı bir gençlik korosu olan Ndlovu Gençlik Korosu, salgına dair farkındalığı artırmak için sanatı çözümün bir parçası olarak kullanmaktadır. Yaş sınırı otuz olan koro üyesi gençler, salgının doğasına, yayılımına, semptomlarına ve korunma yollarına ilişkin doğrulanmamış bilgilerin karşısında, DSö’nün salgına karşı duyurduğu güvenlik önerilerinden hareketle bir şarkı bestelemiş ve bestelerine çektikleri kliple çok sayıda kişiye ulaşmışlardır. 17 yaşında olan koro üyeleri Nonhlanhla Somo ve Lwandile Felicia Shabalala, yaptıkları şarkı ile birçok aile üyesinin tek bir çatı altında yaşadığı ve içme suyu için ortak çeşmeleri kullanmanın zorunlu olduğu bir bölgede fiziksel mesafeyi korumanın oldukça zor olduğuna dikkat çekerek, el yıkama, bir mendile veya dirseğe öksürme, yüze dokunmama veya söylentileri yaymama gibi uyarıların yer aldığı şarkılarıyla salgının yayılımın önlenmesi yönünde verilen mücadelenin bir parçası olduklarını ifade etmişlerdir. Lwandile, koronun şarkıyı ve klipi, insanların doğru bilgiye ulaşarak salgının yayılmasını önlemek için neler yapabileceklerini öğrenmelerine yardımcı olmak için yaptıklarının altını çizmektedir (Thomas, 2020).

\section{Bakım Hareketinden Portatif Lavabolara Amerika Kıtasından İyi Uygulama Örnekleri}

Kanada'da ülkenin her yerinden tıp öğrencileri, 8.000 üyeli 'Kanada Tıp Öğrencileri Federasyonu' çatısı altında sağlık çalışanlarını desteklemek ve gereksinim duyan kişilere yardım etmek için gönüllü bir uygulama yürütmektedir. Bakım hareketi adıyla gerçekleştirdikleri uygulamayla öğrenciler, öncelikle uzun saatler boyunca çalışmak zorunda kalan sağlık çalışanlarına alışveriş, ev işleri ve çocuk bakımı gibi konularda destek olmaya çalışmışlardır. Öğrenciler daha sonra tıp fakülteleriyle ilişkili toplum kuruluşlarına ulaşarak fark yaratabilecekleri yeni ihtiyaçları tespit etmişlerdir. Öğrenciler, halihazırda gereksinim duyulan alanlarda sağladıkları geniş destekle Kanada'da salgınla mücadelede önemli bir rol oynamaktadır. Federasyon başkanı Victor Do, belirsizliğin, korku ve endişenin hâkim olduğu bu süreçte, nezakete ve örnek davranışların yayılmasına ihtiyaç olduğunu ve kendi yaptıklarının da "bu sürecin aşılmasına nasıl yardım edebiliriz?" sorusuna bir cevap niteliğinde olduğunu belirtmektedir. Do, başlattıkları bakım hareketinin aynı dayanışma ruhuyla salgın krizinden sonra da devam edeceğini umduğunu ifade etmektedir (Dyck, 2020).

Oldukça yoksul bir ada ülkesi olan Haiti'de, insanlar yaşanan depremin ve kolera salgının yarattığı olumsuz koşulların yanı sıra eğitim ve sağlık hizmetleri bakımından da yoksunluk yaşamaktadır. Ayrıca Haiti'de pek çok insan, evlerinde kullanabilecekleri bir şebeke suyu bağlantısı ya da su depoları bulunmadığı için ya temiz suyu satın almak ya da çoğunlukla 
kirlenmiş olan su kaynaklarını kullanmak zorunda kalmaktadır. Bunun üzerine izci gençler, salgına dikkat çekmek ve insanların ellerini daha sık yıkayabilmesi için sokaklara portatif lavabolar kurmuşlardır. İzci gençler, bir okulun, yerel yönetim binasının, kilisenin veya işyerinin su kaynağına veya temiz bir kova suya bağladıkları portatif lavaboları, mart ayında başkent Port-au-Prince'in sokaklarında konumlandırmışlardır. Haitililer önce bu uygulama karşısında Tanrının kendilerini koruyacağı için ellerini yıkamaya ihtiyaçları olmadığını ve salgına inanmadıklarını ifade ederek tepki göstermişler ancak daha sonra ellerini yıkayabilmek için çoğu zaman tek fırsatları olan bu uygulamadan memnuniyetle yararlanmaya başlamışlardır (Marsh, 2020).

UNFPA-Karayipler Alt Bölge Ofisi tarafından \#CaribbeanYouthAgainstCOVID19 etiketiyle başlatılan uygulama kapsamında Karayipler'de yer alan ülkelerden gençler, salgından kendilerini, ailelerini, arkadaşlarını ve toplumlarını nasıl koruyabileceklerine dair bilgileri paylaştıkları videolar oluşturarak yayınlamaktadırlar. Örneğin Belize'den Gençlik Danışma Grubu Başkanı Jenean Sabal, videosunda, bu virüsün önlenmesine ilişkin önemli bilgiler paylaşırken, Saint Lucia'dan Jasmyn Joseph ise salgının dünyadaki kadınları ve kız çocuklarını nasıl etkilediğine ve salgın sürecinde toplumsal cinsiyet eşitliğini desteklemek için atılabilecek adımların neler olduğuna değinmektedir (UNFPA Caribbean, 2020).

Arjantin'in yoksul bölgelerinden gelen ve yaşları 6 ile 19 arasında değişen yaklaşık 1.500 genç, yirmi iki yıllık bir müzik programı olan Buenos Aires çocuk ve gençlik korosunda müzik yapmaktadırlar. Alınan karantina önlemleri sırasında koro üyesi gençlerin, salgın sürecinde yaşadıkları korku ve endişeleri geride bırakabilmeleri için müzik çalışmalarına devam edebilmelerinin oldukça önemli olduğu görülmüştür. Bu ihtiyaç üzerine, programın müzik öğretmenlerinden Clarisa Orfila, öğrencileriyle çevrimiçi çalışmalara başlamıştır. Orfila, salgının yarattığı olumsuz koşullara rağmen çevrimiçi çalışmalara katılan öğrencilerin çok iyi bir öğrenme seyri gösterdiklerini, müziğin, zorunlu fiziki mesafenin yaşandığı bu süreçte çalışmalara katılan birçok çocuk ve genç açısından bir topluluk duygusu yaratmaya yardımcı olduğunu ve rahatlama sağladığını ifade etmektedir (Jamal, 2020).

\section{Sonuç ve Öneriler}

2019 yılının son aylarında başlayan ve kısa sürede tüm Dünyayı etkisi altına alan COVID-19 salgını, tüm diğer nüfus grupları gibi gençlerin de sağlıkları başta olmak üzere yaşamlarının tüm yönlerini olumsuz etkilemiştir. COVID-19 salgınının başlangıcından bu yana, yaşlıların ve kronik hastalığı olan kişilerin, salgından daha olumsuz etkilendiği kamuoyuyla paylaşılan mesajların başında gelmiştir. Ancak ilerleyen süreçte, salgının gençlerin fiziksel, zihinsel ve sosyal sağlıkları üzerinde hemen onarılması mümkün olmayan olumsuz etkiler yarattığı da sıklıkla ifade edilmeye başlanmıştır. Bu etkilere 
dikkat çekilmesi ve gençlerin çözümün birer parçası olarak oynadıkları rolün görünür kılınması da son derece önemli hale gelmiştir (UNFPA ve IFRC, 2020, s. 6).

Herkes gibi gençler de bir yandan salgının ortaya çıkarttığı yeni yaşam koşullarına uyum sağlamaya çalışırken bir yandan da sağlıklarını korumaya çalışmaktadırlar. Ancak gençlerin bu süreçteki çabaları bireysel mücadeleler olarak kalmamış, salgına karşı yürütülen toplumsal mücadelenin de önemli birer parçası haline gelmiştir. Gençler, küresel kamuoyunca daha görünür olan sağlık ve sosyal hizmet alanında yürüttükleri özverili mesleki çalışmalarının yanı sıra gerek salgının yayılımının durması ve nihayetinde sonlanması için gerekse salgından olumsuz etkilenen insanların yaşamlarında olumlu bir fark yaratabilmek için son derece önemli uygulamaları hayata geçirmişlerdir.

Dünyanın pek çok yerinde gençler, öncelikle salgına ilişkin bilgilerini arttırarak toplumun diğer üyeleri için yiyecek ve ilaç dağıtımı, dolaşıma sokulan yanlış bilgilerin düzeltilmesi, önleyici tedbirlerin yaygınlaştırılması gibi gönüllü uygulamalara imza atmışlardır. Bu uygulamalar, özellikle halihazırda yoksulluğun ve yurttaşlar arasındaki sosyo-ekonomik uçurumun derin olduğu ve pek çok insanın sağlık, eğitim ve istihdam gibi temel haklarının korunmadığı ülkelerde daha da kritik bir önem taşımaktadır. Zira gençler tarafından salgın sürecinde yürütülen iyi uygulamalarla, doğru bilgiye ve temel hizmetlere ulaşım olanakları kısıtlı olan insanların bilgilendirilmesinde ve yaşadıkları sorunlara ve farklılaşan ihtiyaçlarına dikkat çekilmesinde oldukça önemli bir katkı sağlamaktadırlar.

Amerika Birleşik Devletleri'nde gençlerle gerçekleştirilen geniş çaplı bir araştırmayla gençlerin tamamına yakınının (\%93) yalnızca halk sağlı̆̆ı kurallarına uymakla kalmayıp, aynı zamanda diğer insanlara yardımcı olmak için çabaladıkları ve bu açıdan salgın sürecinde gençler hakkında üretilen bencil ve sorumsuz oldukları yönündeki kalıp yargıların doğru olmadığı ortaya konulmuştur. Ayrıca araştırmaya katılan gençlerin \%84'ünün, tüm gençlerin ailelerine, arkadaşlarına ve toplumlarına yardım etmek için harekete geçebilecekleri yönünde bir inancı paylaştıkları, dolayısıyla salgının ortaya çıkarttığı korku ve kaygıya rağmen gençlerin yalnızca kendilerini düşünmedikleri, toplumdaki diğer insanlara yardım etme ve destek olma açısından da dikkate değer bir istek taşıdıkları görülmüştür (Lundberg ve Junco, 2020).

$\mathrm{Bu}$ nedenle toplumun aktif birer öznesi olarak gençler tarafından salgın sürecinde yürütülen mücadeleler dikkate alınmalı ve daha fazla gencin çözümün bir parçası olarak teşvik edilmesi ve güçlendirilmesi gerekmektedir. Bu nedenle gençlerin salgına ilişkin sürekli olarak güncellenen bilgi platformlarına ulaşımları kolaylaştırılmalı ve teşvik edilmelidir.

Gençler tarafından yürütülen iyi uygulama örneklerinin sosyal medya başta olmak üzere yazılı ve görsel basında yer alması, benzer çabaların yaygınlaşmasını sağlayabilir. Bu 
bağlamda UNFPA tarafından, salgınla mücadelede gençlerin yürüttükleri uygulamaları sosyal medya üzerinden \#YouthAgainstCOVID19 etiketiyle uluslararası bir kampanya yürütülmeye başlanmıştır (Kanem, 2020). Bu tür platformlardan gençlerin haberdar edilmesi ve uygulamalarını paylaşmaları için cesaretlendirilmesi son derece önemlidir. Gençlerin dijital medyayı kullanma becerilerine güvenilmelidir. Zira salgınla ilgili bilgi kirliliğinin ortadan kaldırılarak doğru bilgi kaynaklarının yaygınlaştırılmasında olduğu kadar dijital uçurumun ortadan kaldırılmasında da gençlerin desteği oldukça önemlidir. Özellikle daha ileri yaştaki kişilerin teknolojiyi kullanmalarına yardımcı olma, bu kişilerin doğru bilgiye erişimlerini sağlama, yaşamla ve toplumla bağlarının güçlü kalmasına destek olma, gençlerin uygulamalarıyla yarattığı olumlu sonuçlar arasında öne çıkmaktadır.

Salgın sürecinde evden çıkması mümkün olmayan kişilere temel ve tıbbi ihtiyaç malzemelerinin ulaştırılmasında gençlerin verdiği çabalar son derece önemlidir. Bu çabaların bireyselden toplumsala dönüşmesi, gençler tarafından kurulabilecek gönüllü bir haberleşme ve uygulama ağı ile karşılanması mümkün olabilecektir.

Özetle gençler, salgın sürecinde verilen mücadelenin aktif birer öznesi olarak kendilerinden beklenenin çok ötesinde bir çabayla mücadelenin ön saflarında yer almış ve almaya da devam etmektedirler. Sağlık ve sosyal hizmet çalışanı, araştırmacı, aktivist, toplum gönüllüsü olarak gençlerin güçlerine ve becerilerine güvenilmeli ve iyi uygulamaların geliştirilmesi ve yaygınlaştırılması için gençler teşvik edilmelidir. 


\section{Youth As Active Agents In The Fight Against COVID-19 Best Practice Examples Against The Pandemic From Around The World}

Özge Sanem Özateş Gelmez*

\section{Introduction}

Emerging at the end of 2019 and affecting the entire world in a short period of time, the COVID-19 pandemic has been declared the worst global crisis by the United Nations (UN) since World War II (UNESCO, 2020b). This pandemic has adversely affected the health of people from all population groups around the world. The pandemic has also impacted the health and wellbeing of young people. In addition, young people have been accused of not fulfilling their responsibilities in preventing the spread of the pandemic and acting in a way that places other people at risk. However, responses from young people themselves to these accusations have been largely, if not completely ignored.

In this context, the following questions were asked in this study;

- How are young people affected by the COVID-19 pandemic?

- What are young people expected to do to combat the pandemic?

- What are examples of best practices implemented by young people against the pandemic?

The Predictable Effects of the Pandemic on the Physical, Mental, and Social Health of Young People

The UN has underlined that since the pandemic has caused conditions that negatively affect the physical, mental, and social health of young people, this group is among the most vulnerable to the effects of the COVID-19 pandemic (UNESCO, 2020b).

\footnotetext{
* Assoc. Prof. Hacettepe University, Faculty of Economics and Administrative Sciences, Department of Social Work, Ankara, sanemozge@gmail.com, ORCID: https://orcid.org/0000-0002-5990-4480
} 
Such precautionary measures as closing schools and canceling social activities implemented in many countries have greatly restricted peer relations and socialization among young people. In addition, social isolation and stress are expected to increase the incidences of mental health conditions in young people (Lee, 2020).

OECD findings (2020g, p.11) confirm the profound psychological impact of stress, anxiety, and loneliness brought on by the measures on young people. Moreover, young people from disadvantaged groups are at an even higher risk (UNDESA, 2020), with women, adolescents, and children being at an elevated risk of suffering domestic and/or digital violence (OECD, 2020f, p.24).

UNFPA Executive Director Natalia Kanem's statement on the occasion of the International Youth Day emphasized that during the pandemic, many young people continue to have their rights and choices infringed upon, suffer from a loss of employment, education, and health opportunities, and lack access to essential services (Kanem, 2020).

\section{Expectations from Young People during the COVID-19 Pandemic}

The UN has highlighted the importance of using social media as a tool to promote solidarity, adding that it should be used in a rational and calm manner to support healthy communication and social welfare and so as not to cause panic. In addition, one of the important and urgent steps that young people can easily and universally take to create the rational environment needed is to fact-check any information or news before sharing it (UN, 2020a).

Young people can also become community volunteers who support the elderly and those with chronic diseases by helping them to purchase and deliver groceries and/or medication. Moreover, health workers might need the help of young people to look after their own children or parents in need of care while they attend to life-saving work in clinics and hospitals (UN, 2020a).

Since young people have the power to transform the way adolescent health programs and policies are designed and implemented during and after the pandemic, they should request that they be allowed to participate in strategic plans aiming to restructure the policies, systems, workflows, and communities affected by the pandemic (Efuribe, BarreHemingway, Vaghefi, \& Ballonoff Suleiman, 2020, p.17).

Young people can help mitigate the impact and consequences of the pandemic by building robust, inclusive initiatives on such issues as promoting social cohesion and countering hate speech, xenophobia, human rights violations, and violence (UNFPA \& IFRC, 2020, p.10). Prior to all these proposed interventions, however, the need for young people to take precautionary measures is frequently emphasized-such measures include paying attention to personal care and hygiene, observing physical distance measures, staying 
home when feeling sick, and encouraging other members of society to do the same (WEF, 2020).

\section{Best Practice Examples of Young People in Times of the COVID-19}

In the following section, it has been focused on best practice examples initiated and perpetuated by young people in the face of the pandemic in Asia, Africa, Europe, and America.

Young people worldwide have been taken actions against the pandemic since the beginning of the pandemic. Whereas some of these acts have been carried out as individual initiatives in a limited environment, others have involved large youth organizations and have reached a much wider audience.

\section{Best Practices in Asia: The Raincoat Girl and Coronamap}

Known as the raincoat girl, for the attire she wore while outside in Wuhan, Lu has been cooking meals for the city's medical professionals who unable to eat warm, home-cooked meals between the long working hours (Wickramanayake, 2020). Another individual, Yeritsyan, has been working as a volunteer in the youth organization named Armenian Progressive Youth to help distribute food to elderly people in Armenia unable to leave their homes because of the pandemic (One Young World, 2020; Yeu, 2020). In Bangladesh, Ferdaus and his friends have organized a food and distribution program for sanitizing products among rickshaw puller and daily workers that included an awareness program on the Coronavirus (Women Deliver, 2020; Bracu, 2020). Lee Dong-hun from the Republic of Korea developed a digital application -the Coronamap- as a response to the spread of false information regarding the availability of supplies in his country (Kyoung Mi \& Jihae, 2020).

\section{Best Practices in Europe: Study Rooms and Help at Home}

In Amsterdam, Idrissi -the founder of study rooms- has been delivering food packages and providing laptops and an internet connection to the homes of children whose parents were unemployed during the pandemic (Buijzen, 2020). In Moldova, as part of a UNFPA initiative, young volunteers have been establishing intergenerational bonds with their elders to support them during the pandemic. Specifically, young people who have received training from a psychologist and an epidemiologist have met isolated older persons through phone calls and socially distant visits (UNFPA, 2020). In Bosnia and Herzegovina, volunteer young people have been providing free dog-walking services as part of the program We Walk your Paws for people who have pets and are not allowed to leave their homes as a result of stay-at-home mandates (Sarajevskasehara, 2020). In the UK, an application called Help at Home was developed by Sal Mohammed and the Connected Homeless team. This platform allows isolated citizens to submit requests for help and then connects them with local volunteers capable of fulfilling those requests. Through this program, isolated citizens can 
stay connected with their communities and gain access to essential services (One Young World, 2020).

\section{Best Practices in Africa: Fight Coronavirus Infodemic and One Person, One Sanitizer} More than 5,000 young volunteers in Rwanda have been sharing information about COVID-19 preventive and protective measures in an easy-to-understand language as per the guidelines and protocols outlined by health authorities (Tasamba, 2020). In Zimbabwe, a team of twenty youth volunteers have been working to stop the spread of about COVID19misinformation through social media and radio shows (Harrisberg \& Ndhlovu, 2020). In Cameroon, a youth organization called Local Youth Corner has launched the One Person, One Sanitizer initiative to prevent the spread of coronavirus especially among the poor. Volunteers have been working to produce and distribute free, homemade hand sanitizers using World Health Organization standards (Obonyo, 2020). Ndlovu Youth Choir in South Africa has been using music and dance to dismantle myths about Coronavirus. Said choir created a song named We've Got This and a video to help those who do not have access to accurate information know what to do in order to prevent the virus from spreading (Thomas, 2020).

\section{Best Practices in America: Caremongering and Portable Wash Sinks}

Medical students from across Canada have been working to support health-care professionals as well as offer assistance to vulnerable individuals during the pandemic.

122 They have been doing everything from babysitting children of health-care workers to manning phones at 811 call centers in what they have dubbed Caremongering (Dyck, 2020). In Haiti, young scouts have been setting up portable sinks on the streets to draw attention to the pandemic and to allow people to wash their hands more frequently (Marsh, 2020). Launched by the UNFPA-Caribbean Sub-Regional office under the hashtag \#CaribbeanYouthAgainstCOVID19, young people from Caribbean countries have been creating videos in which they share information with people on how to protect themselves, their families, friends, and communities from the pandemic (UNFPA Caribbean, 2020). Approximately 1,500 young people aged between six and nineteen from low-income areas of Argentina have been playing music in the 22-year-old Buenos Aires Children's and Youth Choir. The classes use music along with video to engage children and help create a sense of community at a time of mandated social distancing (Jamal, 2020).

\section{Conclusion and Recommendations}

In summary, young people play an important role in combating the pandemic. As active agents, they have been at the forefront of the struggle against pandemic and have gone above and beyond what is expected of them. The strength and skills of young people as health and social workers, researchers, activists, and community volunteers should be trusted and encouraged in order to promote the development and dissemination of best practices. 


\section{Kaynakça/References}

- Akat, M. \& Karataş, K. (2020). Psychological effects of COVID-19 Pandemic on society and its reflections on education. Turkish Studies, 15(4), 1-13.

- $\quad$ Brac University (Bracu) (2020, 26 March). Report on Emergency Response on Covid-19 Epidemic Situation in Bangladesh. https://www.bracu.ac.bd/news/report-emergency-response-covid-19epidemic-situation-bangladesh. Erişim tarihi: 05.07.2020.

- Buijzen, J. (2020, 01 April). This Man Helps Hundreds of Amsterdam Children with Homework (And Much More). https://nos.nl/collectie/13839/artikel/2329010-deze-man-helpt-honderdenamsterdamse-kinderen-met-huiswerk-en-veel-meer. Erişim tarihi: 05.07.2020.

- Demir, S. \& Kale M. (2020). Öğretmen görüşlerine göre, Covid-19 küresel salgını döneminde gerçekleştirilen uzaktan eğitim sürecinin değerlendirilmesi. Turkish Studies, 15(8), 3445-3470.

- Dyck, D. (2020, 18 March). Medical Students Form Army of 'Caremongers' during Coronavirus Crisis Social Sharing. https://www.cbc.ca/news/canada/edmonton/medical-students-armycaremongers-coronavirus-crisis-1.5500639. Erişim tarihi: 05.07.2020.

- $\quad$ Efuribe, C., Barre-Hemingway, M., Vaghefi, E. \& Suleiman, A. B. (2020). Coping with the CovID-19 crisis: A call for youth engagement and the inclusion of young people in matters that affect their lives. The Journal of Adolescent Health, 67, 16-17.

- $\quad$ Göksu, Ö. \& Kumcağız, H. (2020). Covid-19 salgınında bireylerde algılanan stres düzeyi ve kaygı düzeyleri. Turkish Studies, 15(4), 463-479.

- Green, P. (2020). Risks to children and young people during covid-19 pandemic. BMJ, 1-2.

- $\quad$ Harrisberg, K. \& Ndhlovu, L. (2020, 23 July). Armed with Social Media, Zimbabwean Youth Fight Coronavirus 'Infodemic'. https://news.trust.org/item/20200723041330-fqvs7. Erişim tarihi: 05.07.2020.

- International Labour Organization (ILO) (2020). Global Employment Trends for Youth 2020. ilo. org/wcmsp5/groups/public/---dgreports/---dcomm/---publ/documents/publication/wcms_737 648.pdf. Erişim tarihi: 05.07.2020.

- Jamal, A. (2020, 31 July). Can't Stop the Music: Argentine Child Orchestras Play on Amid Coronavirus Lockdown. https://www.hindustantimes.com/art-and-culture/can-t-stop-the-music-argentinechild-orchestras-play-on-amid-coronavirus-lockdown/story-S8lUtO1m2E8gbPGPXiOMQK.html. Erişim tarihi: 05.07.2020.

- Kanem, N. (2020, 12 August). Youth Leading the Way in COVID-19 Solutions. https://arabstates. unfpa.org/en/news/youth-leading-way-covid-19-solutions. Erişim tarihi: 05.09.2020.

- $\quad$ Karahan, E., Bozan, M. A. \& Akçay, A. O. (2020). Sinıf öğretmenliği lisans öğrencilerinin pandemic sürecindeki çevrim içi öğrenme deneyimlerinin incelenmesi. Turkish Studies, 15(4), 201-214.

- $\quad$ Kyoung Mi, L. \& Jihae, L. (2020, 30 April). Corona Map Creator Lee Dong-hun. http://www.korea. net/NewsFocus/People/view?articleId=184759. Erişim tarihi: 05.07.2020.

- $\quad$ Lee, J. (2020). Mental health effects of school closures during Covid-19. The Lancet Child \& Adolescent Health, 4(6), 421.

- $\quad$ Lundberg, K. \& Junco, R. (2020, 14 July). Deeply Affected by the Pandemic, Youth are Committed to Helping Others. https://circle.tufts.edu/latest-research/deeply-affected-pandemic-youth-arecommitted-helping-others. Erişim tarihi: 02.09.2020.

- Marsh, S. (2020, 25 March). Haiti's Scouts Set up Mobile Hand Washing Sinks to Ward off Coronavirus. https://www.dailymaverick.co.za/article/2020-03-25-haitis-scouts-set-up-mobilehand-washing-sinks-to-ward-off-coronavirus/. Erişim tarihi: 05.07.2020.

- Obonyo, R. (2020, 01 May). Youth Key in Fight Against Coronavirus. https://blogs.worldbank.org/ youth-transforming-africa/youth-key-fight-against-coronavirus. Erişim tarihi: 05.07.2020. 
- One Young World (2020). Ambassadors Eading Action in Europe on COVID-19. https://www. oneyoungworld.com/coronavirus-response-europe. Erişim tarihi: 07.07.2020.

- Organisation for Economic Cooperation and Development (OECD) (2020a). COVID-19: Protecting People and Societies. https://read.oecd-ilibrary.org/view/?ref=126_126985nv145m3l96\&title=COVID-19-Protecting-people-and-societies. Erişim tarihi: 03.07.2020.

- Organisation for Economic Cooperation and Development (OECD) (2020b). How's Life 2020 Measuring Well-Being. https://www.oecd-ilibrary.org/docserver/9870c393-en. pdf?expires=1599561607\&id=id\&accname=guest\&checksum=46505187CFAC6517EC4651730B2417D1. Erişim tarihi: 10.07.2020.

- Organisation for Economic Cooperation and Development (OECD) (2020c). Learning Remotely When Schools Close: How Well Are Students and Schools Prepared? Insights from PISA. https://read. oecd-ilibrary.org/view/?ref=127_127063-iiwm328658\&title=Learning-remotely-when-schoolsclose. Erişim tarihi: 10.07.2020.

- Organisation for Economic Cooperation and Development (OECD) (2020d, 13 May). OECD Unemployment Rate up Sharply in March 2020 with Data for April Pointing to an Unprecedented Rise. http://www.oecd.org/sdd/labour-stats/unemployment-rates-oecd-update-may-2020.htm. Erişim tarihi: 07.07.2020.

- Organisation for Economic Cooperation and Development (OECD) (2020e, 07 July). Urgent Action Needed to Stop Jobs Crisis Becoming a Social Crisis. https://www.oecd.org/newsroom/urgentaction-needed-to-stop-jobs-crisis-becoming-a-social-crisis.htm. Erişim tarihi: 10.09.2020.

- Organisation for Economic Cooperation and Development (OECD) (2020f). Women at the Core of the Fight against COVID-19 Crisis. https://read.oecd-ilibrary.org/view/?ref=127_127000awfnqj80me\&title=Women-at-the-core-of-the-fight-against-CovID-19-crisis. Erişim tarihi: 03.07.2020.

124 - Organisation for Economic Cooperation and Development (OECD) (2020g). Youth and Covid-19 Response, Recovery, Resilience. https://read.oecd-ilibrary.org/view/?ref=134_134356ud5kox3g26\&title=Youth-and-COVID-19-Response-Recovery-and-Resilience. Erişim tarihi: 03.07.2020.

- $\quad$ Öncen, S., Aydın, S. \& Molla, E. (2020). CovID-19 pandemisi döneminde sokağa çıkma sınırlaması olan ve olmayan illerde yaşayan spor bilimleri öğrencilerinin fiziksel aktivite düzeylerinin değerlendirmesi. Turkish Studies, 15(6), 739-749.

- $\quad$ Ragavan, M. I., Culyba, A. J., Muhammad, F. L. \& Miller, E. (2020). Supporting adolescents and young adults exposed to or experiencing violence during the COVID-19 pandemic. The Journal of Adolescent Health, 67, 18-20.

- Sarajevskasehara (2020, 28 March). Šetamo Šapice: Tim Volontera Šeta Kućne Ljubimce Za Vrijeme Ograničenja U Sarajevu. https://sarajevskasehara.com/2020/03/setamo-sapice-tim-volonteraseta-kucne-ljubimce-za-vrijeme-ogranicenja-u-sarajevu/?fbclid=IwARlfAOnvhZu3KgaGCkABmsS n5064kRSPVlwNsEjFSShb8A-fe2F1ghk3Q38. Erişim tarihi: 05.07.2020.

- Tasamba, J. (2020, 06 June). Rwandan Youth Volunteers Helping Fight against COVID-19. https:// www.aa.com.tr/en/africa/rwandan-youth-volunteers-helping-fight-against-covid-19/1867456. Erişim tarihi: 05.07.2020.

- Tekin, E. (2020). COVID-19 kaygısının motivasyon üzerindeki etkisi: Z Kuşağ üzerine bir araştırma. Turkish Studies, 15(4), 1129-1145.

- Thomas, T. (2020, 09 April). Two Members of South Africa's Ndlovu Youth Choir Discuss Their Hit Song about Preventing the Spread of COVID-19. https://assembly.malala.org/stories/ndlovuyouth-choir-coronavirus-song. Erişim tarihi: 05.07.2020.

- United Nations (UN) (2020a). 5 Things Young People can do to Join the Global \#COVID19 Response. 
https://www.un.org/youthenvoy/2020/03/5-things-young-people-can-do-against-coronavirus/. Erişim tarihi: 01.07.2020.

- United Nations (UN) (2020b, 27 April). Disproportionately Affected Youth must be Central to COVID-19 Pandemic Recovery Plans, Experts Tell Security Council, Stressing Their Key Role as GameChangers. https://www.un.org/press/en/2020/sc14170.doc.htm. Erişim tarihi: 01.07.2020.

- United Nations Department of Economic and Social Affairs (UNDESA) (2020, 5 May). Protecting and Mobilizing Youth in COVID-19 Responses. https://www.un.org/development/desa/dpad/ publication/un-desa-policy-brief-67-protecting-and-mobilizing-youth-in-covid-19-responses/. Erişim tarihi: 03.07.2020.

- United Nations Educational, Scientific and Cultural Organization (UNESCO) (2020a). COVID-19 Impact on Education. https://en.unesco.org/covid19/educationresponse. Erişim tarihi: 01.09.2020.

- United Nations Educational, Scientific and Cultural Organization (UNESCO) (2020b, 30 June). Youth, Strategic Partners during the COVID-19 Crisis. https://en.unesco.org/news/youth-strategicpartners-during-covid-19-crisis. Erişim tarihi: 03.07.2020.

- United Nations Population Fund (UNFPA) (2020, 13 August). Meeting the needs of older people through solidarity, empowerment and data. https://www.unfpa.org/news/meeting-needs-olderpeople-through-solidarity-empowerment-and-data. Erişim tarihi: 05.07.2020.

- United Nations Population Fund Sub-Regional Office for the Caribbean (UNFPA Caribbean) (2020). \#CaribbeanYouthAgainstCOVID19 and \#YouthAgainstCOVID19. https://caribbean.unfpa.org/en/ videos?page=2 Erişim tarihi: 06.07.2020.

- United Nations Population Fund (UNFPA) \& International Federation of the Red Cross and Red Crescent Societies (IFRC) (2020). COVID-19: Working with and for Young People. https:// www.unfpa.org/resources/covid-19-working-and-young-people\#: :text=It\%20begins\%20 diagnostically\%2C\%20exploring \%20the,with\%20and\%20for\%20young\%20people. Erişim tarihi: 10.07.2020.

- Wickramanayake, J. (2020, 03 April). Meet 10 Young People Leading the COVID-19 Response in Their Communities. Africa Renewal. https://www.un.org/africarenewal/web-features/coronavirus/ meet-10-young-people-leading-covid-19-response-their-communities. Erişim tarihi: 05.07.2020.

- World Health Organization (WHO) (1948, 07 April). What is the WHO definition of health?. https:// www.who.int/about/who-we-are/frequently-asked-questions. Erişim tarihi: 06.07.2020.

- World Health Organization (WHO) (2020, 15 February). WHO Director-General/Speeches/Detail/ Munich Security Conference. https://www.who.int/dg/speeches/detail/munich-securityconference. Erişim tarihi: 06.07.2020.

- Women Deliver (2020). 10 Ways Young People Are Leading the Way Against COVID-19. https:// womendeliver.org/2020/10-ways-young-people-are-leading-the-way-against-covid-19/. Erişim tarihi: 06.07.2020.

- World Economic Forum (WEF) (2020). How Young People Can Help Respond to The Coronavirus Outbreak. https://www.weforum.org/agenda/2020/03/coronavirus-global-shapers-youngpeople-response/. Erişim tarihi: 10.07.2020.

- Yeu (Youth for exchange and understanding), (2020, 29 April). Armenian Progressive Youth (APY) Responds to Covid-19 Outbreak in Armenia. http://www.yeu-international.org/en/publications/ newsmail/news/armenian-progressive-youth-apy-responds-to-covid-19-outbreak-in-armenia. Erişim tarihi: 05.07.2020. 